\title{
Analisis Konsistensi Respon Siswa SMA terhadap Tes Representasi Majemuk dalam Pembelajaran Fisika Materi Gerak Lurus
}

\author{
Ahmad, Muslimin dan Darsikin \\ mufiahahmad@gmail.com \\ Program Studi Pendidikan Fisika FKIP Universitas Tadulko \\ Jl. Soekarno Hatta Km. 9 Kampus Bumi Tadulako Tondo Palu - Sulawesi Tengah
}

\begin{abstract}
Penelitian ini adalah deskriptif kualitatif dengan tujuan untuk mendeskripsikan hasil Analisis Konsistensi Respon Siswa SMA kelas XI Terhadap Tes Representasi Majemuk dalam Pembelajaran Fisika Materi Gerak Lurus. Subjek penelitian ini adalah siswa kelas XI di SMA Negeri 5 Palu. Subyek penelitian ini terdiri dari 31 orang siswa yang turut serta dalam Tes Representasi dan dipilih 6 responden diminta mengikuti wawancara berdasarkan tingkat konsistensinya. Instrumen penelitian yang digunakan terdiri dari 18 soal Tes representasi PG. Soal tersebut digunakan untuk memilih responden yang berjumlah 6 orang. Pada tahap wawancara responden menjelaskan alasan yag berhubungan dengan jawaban yang dipilih. Data diperoleh melalui lembar jawaban siswa dan rekaman hasil wawancara. Data penelitian dianalisis melalui pendekatan deskriptif kualitatif. Hasil penelitian ini menunjukkan bahwa tingkat kekonsistenan siswa berbeda-beda pada tiap jenis representasi, sebagian besar siswa berada pada tingkat konsisten dan tidak konsisten sedangkan yang sangat konsisten hanya sebagian kecil.
\end{abstract}

Kata Kunci: Konsistensi Respon dan Representasi Majemuk

\section{PENDAHULUAN}

Peran multi representasi dalam pembelajaran merupakan topik penting di bidang penelitian pendidikan. Multi representasi misalnya, teks, diagram, grafik dan persamaan sering diperlukan untuk memahami konsep-konsep ilmiah dan untuk pemecahan masalah.

Nguyen dan Rebello menunjukkan bahwa penggunaan beberapa representasi dalam proses belajar mengajar dapat membantu siswa menjadi lebih baik dalam memecahkan masalah, tetapi ada beberapa siswa yang kesulitan dengan beberapa representasi ${ }^{[1]}$.

Salah satu alasan fisika dikatakan pelajaran yang sulit karena fisika menuntut siswa untuk menguasai representasi-representasi berbeda. Hal ini berarti siswa harus memiliki kemampuan berfikir, kemampuan bekerja, kemampuan bersikap ilmiah, dan kemampuan memecahkan masalah sehingga siswa diharapkan memiliki kemampuan untuk merepresentasi suatu informasi dengan banyak cara ${ }^{[2]}$.

Multirepresentasi dianggap kunci untuk belajar fisika sehingga ada motivasi yang cukup baik untuk mempelajari bagaimana siswa menggunakan multirepresentasi saat memecahkan masalah dan belajar bagaimana cara terbaik untuk mengajarkan pemecahan masalah dengan menggunakan multirepresentasi ${ }^{[3]}$.
Meskipun

menggunakan

beberapa representasi dalam mengajar memiliki potensi manfaat yang besar, juga dapat membahayakan proses pembelajaran, karena beban kognitif meningkat. Ada sejumlah tugas kognitif bahwa siswa harus melakukan beberapa representasi, mereka harus belajar format dan operator masing-masing representasi, di bawah hubungan antara representasi dan domain itu mewakili, dan memahami bagaimana representasi berhubungan satu sama lain.

Pentingnya multirepresentasi juga telah dilaporkan dalam penelitian pendidikan fisika, Nieminen Ia, menawarkan beberapa alasan mengapa beberapa representasi berguna dalam pendidikan fisika: mereka mendorong siswa di bawah masalah fisika, membangun jembatan antara lisan dan representasi matematika, dan membantu siswa mengembangkan gambar yang memberi makna simbol-simbol matematika. Peneliti ini juga berpendapat bahwa salah satu tujuan penting dari pendidikan fisika membantu siswa untuk belajar membangun beberapa representasi dari proses fisik, dan belajar untuk bergerak segala arah antara representasi ini. Selain itu, telah ditunjukkan bahwa dalam rangka untuk memahami konsep fisika, kemampuan untuk mengenali dan memanipulasi bahwa konsep dalam berbagai representasi sangat penting ${ }^{[4]}$. 
Wadrip dan Prain menyatakan bahwa pemberian soal-soal latihan atau ujian dan tugas yang tergolong sulit dapat meningkatkan kemampuan representasi siswa karena dalam soal yang tergolong sulit tersebut siswa dituntut untuk mengerahkan semua kemampuan yang dimilikinya sehingga siswa dapat menyelesaikan soal-soal fisika dengan sukses dan hasil belajar siswa dapat mengalami peningkatan ${ }^{[5]}$.

Studi lain menunjukkan bahwa format representasi di mana masalah ini diajukan mempengaruhi kinerja siswa. Baik konteks dan representasi mempengaruhi respon siswa. Siswa mungkin dapat menerapkan konsep dalam konteks familiar menggunakan representasi tertentu tetapi gagal ketika konteks atau representasi berubah. Untuk mengevaluasi konsistensi representasi siswa, yaitu, kemampuan mereka untuk menggunakan representasi yang berbeda secara konsisten secara ilmiah benar atau salah antara isomorfik dengan konteks dan konten semirip mungkin.

Berdasarkan penjelasan tersebut, peneliti tertarik untuk melakukan penelitian yang dapat menggambarkan dan menjelaskan konsistensi respon siswa terhadap tes representasi majemuk. Soal yang digunakan untuk mengukur kemampuan representasi berbentuk pilihan ganda dengan representasi yang berbeda untuk setiap pertanyaan dan pilihan jawaban konsep-konsep.

\section{METODE PENELITIAN}

Jenis penelitian ini yaitu deskriptif kualitatif yang bertujuan untuk mendeskripsikan konsistensi respon siswa terhadap tes representasi majemuk dalam pembelajaran fisika, tes representasi berupa teks, diagram, grafik dan persamaan.

Rancangan penelitian dalam penelitian ini yaitu diberikan tes pembelajaran fisika pilihan ganda dalam berbagai jenis reprentasi yang dirangkaikan dengan wawancara semistructured dan selanjutnya dari data-data yang diperoleh dari kegiatan diatas dianalisis. Penelitian ini dilakukan di salah satu Sekolah Menengah Atas di kota Palu, Tahun Ajaran 2014/2015. Penelitian dilaksanakan selama dua minggu dengan intensitas tatap muka dengan responden sebanyak dua kali. Satu kali untuk pemberian Tes konsistensi representasi dan satu kali untuk wawancara kepada responden terpilih.

Penelitian ini menggunakan instrumen berupa tes representase yang berbentuk tes pilihan ganda yang terdiri dari delapanbelas buah soal. Setiap soal telah divalidasi oleh validator ahli.
Data di peroleh dari siswa melalui pemberian tes dalam beberapa butir soal fisika yang telah diajarkan oleh Guru Matapelajaran Fisika, serta perolehan informasi dari wawancara langsung dengan beberapa siswa.

\section{HASIL DAN PEMBAHASAN}

Kemampuan representasi merupakan sesuatu yang dapat dilakukan siswa untuk menggambarkan suatu bentuk representasi kebentuk representasi lainnya. Penelitian ini menitikberatkan pada konsistensi representasi siswa dalam pembelajaran fisika, aspek kebenaran atau kesalahan jawaban tidak menjadi fokus dalam pembahasan penelitian ini. Peneliti hanya mengungkapkan dan mendeskripsikan dari konsistensi representasi siswa.

Berdasarkan Tabel 1 dapat diketahui bahwa setiap siswa merespon setiap reprepresentasi berbeda-beda setiap temanya. Tabel di atas juga tampak bahwa hanya terdapat satu responden yang berada pada tingkat konsistensi sangat konsisten. hal ini karena responden tidak mengingat konsep, sehingga responden lebih banyak meniru soal yang telah dikerjakan yang menggunakan konsep yang sama.

Tema satu mengenai konsep jarak dan perpindahan dengan bentuk representasi matematis, soal tentang membedakan jarak dan perpindahan berdasarkan perhitungan matematis, dari 31 responden terdapat 21 responden atau sebesar $67,7 \%$ yang konsisten untuk representasi matematis pada tema satu. Representasi verbal pada tema satu dengan soal mengenai perbandingan jarak dan perpindahan suatu benda melalui deskripsi verbal, dari 31 responden terdapat 15 responden yang konsisten atau sebesar 48,4\% yang konsisten untuk representasi verbal pada tema satu. Representasi gambar pada tema satu dengan soal mengenai penggambaran gerak dari suatu benda, dari 31 responden hanya 8 responden yang konsisten atau sebesar $25,8 \%$ yang konsisten untuk representasi gambar pada tema satu. 
Tabel 1 Poin Konsistensi Responden Setiap Tema

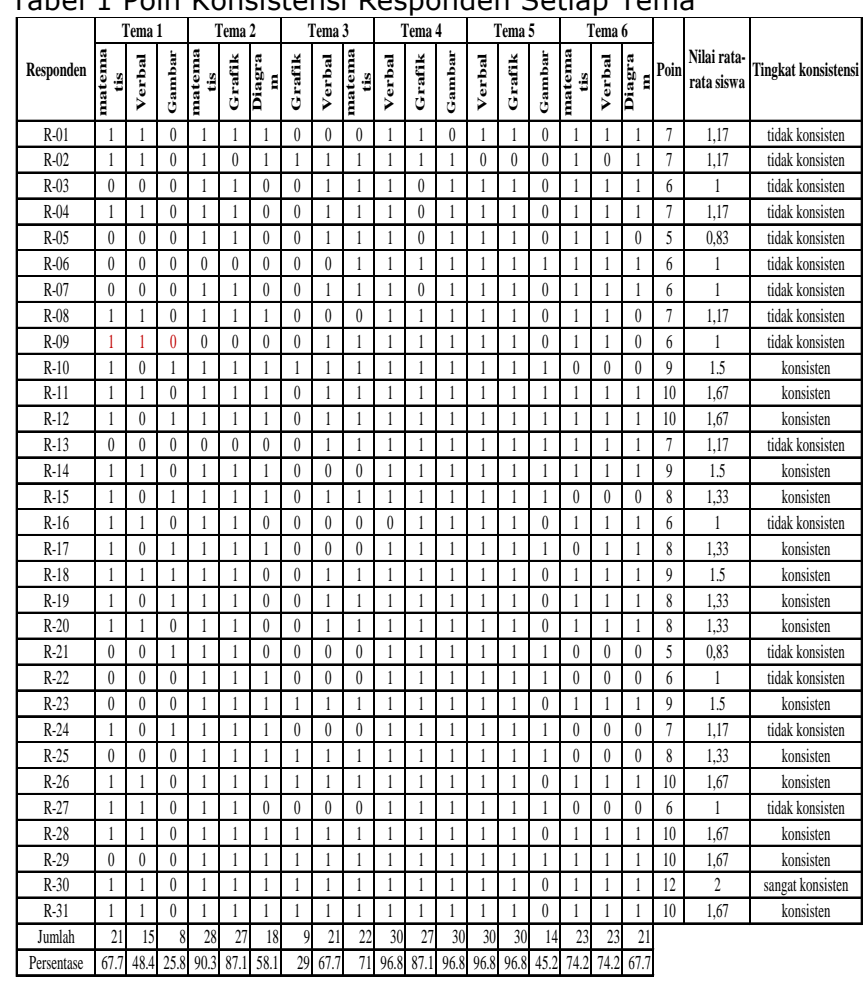

Tema dua mengenai konsep kecepatan dengan bentuk representasi matematis, yaitu menghitung nilai kecepatan benda berdasarkan data, dari 31 responden terdapat 28 responden atau sebesar $90,3 \%$ yang konsisten untuk representasi matematis pada tema dua. Representasi grafik pada tema dua dengan soal mengenai penggambaran grafik kecepatan berdasarkan data jarak tempuh, dari 31 responden terdapat 27 responden yang konsisten atau sebesar $87,1 \%$ yang konsisten untuk representasi grafik pada tema dua. Representasi diagram pada tema dua dengan soal mengenai mendiagramkan perbandingan kecepatan dua buah benda, dari 31 responden terdapat 18 responden yang konsisten atau sebesar $58,1 \%$ yang konsisten untuk representasi grafik pada tema dua.

Tema tiga mengenai konsep percepatan dengan bentuk representasi grafik, soal tentang menggambarkan grafik dari data perubahan kecepatan benda, dari 31 responden hanya terdapat 9 responden atau sebesar 29\% yang konsisten untuk representasi grafik pada tema tiga. Representasi verbal pada tema tiga dengan soal mengenai membandingkan kecepatan benda berdasarkan data melalui deskripsi verbal, dari 31 responden terdapat 21 responden yang konsisten atau sebesar $67,7 \%$ yang konsisten untuk representasi verbal pada tema tiga. Representasi matematis pada tema tiga dengan soal mengenai menyatakan perbandingan percepatan beberapa benda dengan simbol matematis, dari 31 responden terdapat 22 responden yang konsisten atau sebesar $71 \%$ yang konsisten untuk representasi matematis pada tema tiga.

Tema empat mengenai konsep Gerak Lurus Beraturan (GLB) dengan bentuk representasi verbal, soal tentang menyatakan jenis gerak benda yang bergerak dengan kecepatan konstan dari data rekam jejak pita, dari 31 responden terdapat 30 responden atau sebesar $96,8 \%$ yang konsisten untuk representasi verbal pada tema empat. Representasi grafik pada tema empat dengan soal mengenai menggambarkan grafik dari benda yang bergerak dengan kecepatan konstan, dari 31 responden terdapat 27 responden yang konsisten atau sebesar $87,1 \%$ yang konsisten untuk representasi verbal pada tema empat. Representasi gambar pada tema empat dengan soal mengenai menggambarkan rekam jejak benda yang bergerak dengan kecepatan konstan, dari 31 responden terdapat 30 responden yang konsisten atau sebesar 96,8\% yang konsisten untuk representasi gambar pada tema empat.

Tema lima mengenai konsep Gerak Lurus Berubah Beraturan (GLBB) dengan bentuk representasi verbal, soal tentang menyatakan jenis gerak benda yang bergerak denan percepatan konstan dari data gerak benda, dari 31 responden terdapat 30 responden atau sebesar $96,8 \%$ yang konsisten untuk representasi verbal pada tema lima. Representasi grafik pada tema lima dengan soal mengenai mengambarkan grafik dari sebuah benda yang mengalami gerak lurus dengan percepatan konstan, dari 31 responden juga terdapat 30 responden yang konsisten atau sebesar $96,8 \%$ yang konsisten untuk representasi grafik pada tema lima. Representasi gambar pada tema lima dengan soal mengenai penggambaran rekam jejak benda yang bergerak lurus dengan percepatan konstan , dari 31 responden terdapat 14 responden yang konsisten atau sebesar $45,2 \%$ yang konsisten untuk representasi gambar pada tema lima.

Tema enam mengenai konsep gerak jatuh bebas dengan bentuk representasi matematis, soal tentang menyatakan perbandingan waktu tempuh sampai ke tanah beberapa benda berbeda yang mengalami jatuh bebas berdasarkan perhitungan matematis, dari 31 responden terdapat 23 responden atau sebesar $74,2 \%$ yang konsisten untuk representasi matematis pada tema enam. Representasi verbal pada tema enam dengan soal mengenai menyatakan perbandingan waktu tempuh sampai ke tanah beberapa benda berbeda yang 
menalami jatuh bebas dengan pernyataan verbal, dari 31 responden terdapat 23 responden yang konsisten atau sebesar $74,2 \%$ yang konsisten untuk representasi verbal pada tema enam. Representasi diagram pada tema enam dengan soal mengenai menentukan diagram perbandingan waktu sampai ke tanah untuk tiga buah benda yang mengalami jatuh bebas, dari 31 responden terdapat 21 responden yang konsisten atau sebesar $67,7 \%$ yang konsisten untuk representasi gambar pada tema enam.

Berdasarkan hasil analisis yang dilakukan pada saat siswa menjawab soal dan melihat hasil jawaban siswa, dapat dilihat bahwa konsistensi representasi yang dimiliki oleh setiap siswa berbeda-beda. Berdasarkan hasil dari pemberian tes representase diperoleh persentase konsistensi representase siswa pada masing-masing representase dapat dilihat pada Tabel 2.

Tabel 2 Persentase Representasi Siswa

Tabel 2 Persentase Representasi Siswa
\begin{tabular}{|c|c|c|c|}
\hline Nomor & Representase & $\begin{array}{c}\text { Skor Rata- } \\
\text { Rata (\%) }\end{array}$ & $\begin{array}{c}\text { Kategori } \\
\text { Berdasarkan } \\
\text { Depdiknas }\end{array}$ \\
\hline 1 & Verbal & 76,77 & Tinggi \\
\hline 2 & Matematis & 75,81 & Tinggi \\
\hline 3 & Grafik & 75,00 & Tinggi \\
\hline 4 & Diagram & 58,71 & Sedang \\
\hline
\end{tabular}

Berdasarkan tabel 2 hasil jawaban tes multi representasi responden, tingkat presentase penggunaan format representasi secara berturut dari yang tinggi yaitu format verbal $(76,77 \%)$, format matematis $(75,81 \%)$, dan format grafik $(75,00 \%)$ dan yang sedang yaitu format diagram $(58,71 \%)$. Sehingga responden pada penelitian ini menunjukkan penguasaan format verbal, matematis, dan grafik yang lebih dipilih dalam menyelesaikan tes multi representasi tentang Gerak Lurus.

Tingkat format representasi dari hasil penelitian ini sama halnya dengan penelitian terdahulu oleh Meltzer yang menempatkan penggunaan format verbal pada urutan pertama disusul format grafik dan format diagram. Hal ini dimungkinkan karena responden lebih terbiasa menyelesaikan soalsoal matematis dan lebih mudah memahami soal-soal format verbal ${ }^{[6]}$.

Berdasarkan hasil wawancara diketahui bahwa siswa cenderung menghafalkan rumusrumus matematik. Jika siswa tidak hafal rumus yang dipakai dalam menyelesaikan suatu soal maka mahasiswa tidak dapat menyelesaikan dengan baik atau bahkan memutuskan untuk menjawab dengan menebak. Hal ini sejalan dengan temuan Kohl and Noah yang

menyatakan bahwa siswa fisika tahun pertama lebih nyaman dengan soal-soal matematik dari pada soal-soal konsep ${ }^{[3]}$.

Berdasarkan hasil penjelasan di atas dapat dilihat bahwa konsistensi representasi siswa dari keempat representasi yang ditawarkan, representasi diagram yang memperoleh kategori sedang. Hal ini disebabkan oleh sebagian besar siswa kesulitan memahami nilai-nilai yang disajikan dalam bentuk diagram, ketika mereka memecahkan masalah fisika, mereka menggunakan masalah untuk menemukan jawaban tetapi mereka kurang memahami masalah pada fisika.

\section{Tema Satu, Konsep Jarak dan Perpindahan}

Pemahaman responden pada tema satu tentang konsep jarak dan perpindahan. Soal yang mendeskripsikan tentang jarak dan perpindahan berdasarkan perhitungan matematis, format verbal dengan menyatakan perbandingan jarak dan perpindahan suatu benda, dan format gambar dengan menggambarkan gerak dari suatu benda, dapat dilihat pada kutipan wawancara berikut.

(Matematis)

Interviewer : masih ingat jawaban yang nomor 1?, bisa jelaskan mengapa memilih jawaban itu.

$\mathrm{R}-23$ Jawaban saya bagian A eh bukan E. karena besar jarak dan perpindahannya itu sama $100 \mathrm{~km}$

Interviewer : Bagaimana kamu menentukannya?

$\mathrm{R}-23$

Interviewer Hmmm, konsep apa. Konsep itu seperti apa

$\mathrm{R}-23$

Interviewer

$\mathrm{R}-23$

Interviewer

$\mathrm{R}-23$

Interviewer

$\mathrm{R}-23$

Interviewer

$\mathrm{R}-23$

Interviewer

Mengerti konsep jarak dan perpindahan?

Jarak adalah perpindahan Dengan? Apa yang dihitung. Jarak dan perpindahan.

Menurut ade, jarak dan perpindahan itu seperti apa?

Bingung

Misalnya dari A ke B kemudian ke C, mana jarak dan perpindahan?

A ke B ke C jarak kak. Kalau perpindahan?

Apa bedanya kak? Sama saja Kalau perpindahan itu dari A ke C

(Verbal)

Interviewer

$\mathrm{R}-23$

Interviewer

R-23

Interviewer

$\mathrm{R}-23$

Interviewer

$\mathrm{R}-23$
Nomor 2 jawabannya?

$<$ membaca soal> jawaban saya $\mathrm{C}$

Kenapa memilih C?

Karena besar jarak tempuhnya sama,

Konsepnya bagaimana?

Sama seperti nomor 1 kak.

Berarti jarak dan perpindahan sama?

Iya sama. 
(Gambar)

Interviewer

Nomor 3, masih ingat pilih jawaban yang mana?

$\mathrm{R}-23$ $<$ membaca soal $>$ jawaban saya A

Interviewer Kenapa memilih A diantara semua pilihan jawaban?

Karena yang A tepat sama soalnya,kalo yang lain tidak sesuai sama data disoal.

R-23 dalam merespon setiap soal tes representasi dalam hal ini representasi matematis, verbal, dan gambar pada tema satu mengenai jarak dan perpindahan dengan respon yang sama bahwa jarak dan perpindahan sama, menurut R-23 jarak dan perpindahan sama yaitu jarak dari titik A ke titik B dan ke titik C hal ini diterapkan pada setiap representasi pada konsep jarak dan perpindahan.

Pada tema ini dari ketiga reprepresentasi yang disajikan, yaitu matematis, verbal, dan gambar hampir semua siswa merespon representasi yang diberikan dengan tidak konsisten dalam membedakan jarak dan perpindahan. Pada representasi matematis beberapa responden mendefinisikan jarak dan perpindahan sama kemudian sama halnya juga pada representasi verbal. Lalu pada representasi gambar, responden mendefinisikan jarak dan perpindahan tidaklah sama. Sehingga responden dinyatakan tidak konsisten pada tema ini.

Penelitian yang digunakan oleh Rosengrant yang menggunakan soal pilihan ganda pada materi Hukum Newton menunjukkan bahwa representasi matematis memiliki nilai paling rendah dibandingkan dengan representasi lain. Hal ini disebabkan karena siswa kurang memahami persamaan atau rumus dalam fisika. Menurut Rosengrant ketika mereka memecahkan masalah fisika, mereka menggunakan masalah untuk menemukan persamaan dalam menghitung jawaban tetapi mereka kurang memahami masalah pada fisika ${ }^{[7]}$.

\section{Tema Dua, Konsep Kecepatan}

Pemahaman responden pada tema kedua tentang kecepatan. Soal tentang kecepatan benda berdasarkan perhitungan matematis dengan menghitung nilai kecepatan benda berdasarkan data yang diberikan, menggambarkan grafik, dan membuatkan diagram perbandingan kecepatan dua benda dapat dilihat pada kutipan wawancara berikut.
(Matematis)

Interviewer : Nomor 4, masih ingat jawabannya? kenapa memilih jawaban yang itu?

$\mathrm{R}-05$

$<$ membaca soal> berarti kan dalam waktu 15 detik menempuh jarak 600 berarti kan dia dalam waktu 20sekon sampai ditengahnya jarak itu, jawabannya D.

Interviewer : Menurut kamu konsep apa yang digunakan pada nomor 4? Dia menjelaskan tentang apa?.

R-05 : Mencari kecepatan mobil, berarti kecepatan

Interviewer Kecepatan itu seperti apa?

R-05 $\mathrm{m} / \mathrm{s}$, dia kan ada jarak sama waktunya

(Grafik)

Interviewer : Nomor 5, masih ingat jawaban yang kamu pilih? Alasan memilih jawaban tersebut apa?

R-05 : Yang A, karena dia kan dalam waktu 10detik mobil balap Mail menempuh jarak 200m yang Kevin cuma 100 jadi perbandingannya 10 per 20.

Interviewer : konsep apa yang dipakai pada nomor 5 ini?

$\mathrm{R}-05$

(Diagram)

Interviewer

$<$ diam> konsep kecepatan

R-05

Nomor 6 masih ingat jawabannya? bagaimana kamu menjelaskan pilihan jawabanmu?

$<$ membaca soal $>$ saya pilih $D$ karena kan Rumah Romi dan Kardun beda, kalo jarak rumah Romi $2 \mathrm{~km}$ sedangkan Kardun $1 \mathrm{~km}$ baru kan sampainya sama, jadi perbandingannya sama karena sampai bersamaan sama-sama setengah jam.

Interviewer Soal ini membicarakan tentang apa?

R-05 Kecepatan, karena kan ditanya perbandingan kecepatannya

R-05 dalam merespon setiap soal tes representasi dalam hal ini representasi matematis, verbal, dan gambar pada tema dua tentang kecepatan dengan respon yang sama mengenai kecepatan dan R-05 juga menggunakan masalah untuk menemukan persamaan atau rumus dalam fisika dalam menghitung jawaban tetapi mereka kurang memahami masalah fisika, hal ini terlihat pada representasi diagram, ia menyatakan bahwa kalau jarak rumah Romi $2 \mathrm{~km}$ sedangkan Kardun $1 \mathrm{~km}$ dan sampainya bersamaan, berarti perbandingannya sama karena sampai bersamaan sama-sama setengah jam.

Pada tema ini dari ketiga reprepresentasi yang disajikan, yaitu matematis, grafik, dan diagram hampir semua siswa merespon representasi yang diberikan dengan konsisten dalam menentukan kecepatan benda. Pada representasi matematis, grafik, dan diagram 
sebagian besar responden menyatakan perbandingan kecepatan dua buah benda adalah sama tanpa memperhatikan variabel lain yang berbeda pada soal yang disajikan, hal ini responden terapkan pada setiap format yang disajikan pada tema dua dengan konsep kecepatan.

\section{Tema Tiga, Konsep Percepatan}

Pemahaman R-23 dapat dilihat pada tema ketiga tentang konsep percepatan. Soal tentang percepatan berdasarkan format grafik dengan penggambaran grafik dari data perubahan kecepatan benda, format verbal dengan membandingkan percepatan benda berdasarkan data, dan format matematis dengan menyatakan perbandingan percepatan beberapa benda, dapat dilihat pada kutipan wawancara berikut.

(Grafik)

Interviewer : masih ingat jawaban yang nomor 7?, bisa jelaskan mengapa memilih jawaban itu.

R1 : <membaca soal> C saya kak.

Interviewer : Kenapa memilih C? disini kamu pertama memilih $D$ tapi kemudian dicoret menjadi C kenapa?.

R1

Interviewer : Soal ini membicarakan tentang

R1 : Kecepatan kak, tapi tidak ingat apa? definisinya.

(Verbal)

Interviewer : masih ingat jawaban yang nomor 8 ?

$\begin{array}{lll}\text { R1 } & \text { <membaca soal> D kak. } \\ \text { Interviewer } & : \text { Jawaban kamu lalu A kenapa }\end{array}$

$\mathrm{R} 1$ berubah lagi?

Hmmm,

(Matematis)

Interviewer

masih ingat jawaban yang nomor 9 ?

R1

Interviewer

R1

Interviewer

R1

$<$ membaca soal> A mungkin kak.

Bagaimana kamu mendefinisikan jawaban kamu?

$$
\text { Hmmm, }
$$

Soal ini membicarakan tentang apa?

Percepatan kak

R-01 dalam merespon setiap soal tes representasi dalam hal ini representasi grafik, verbal dan matematis pada tema tiga tentang percepatan dengan respon yang sama mengenai kecepatan dan R-05 juga menggunakan masalah untuk menemukan persamaan atau rumus dalam fisika dalam menghitung jawaban tetapi mereka kurang memahami masalah fisika, hal ini terlihat pada representasi diagram, ia menyatakan bahwa kalau jarak rumah Romi $2 \mathrm{~km}$ sedangkan Kardun $1 \mathrm{~km}$ dan sampainya bersamaan,

berarti perbandingannya sama karena sampai bersamaan sama-sama setengah jam.

Pada tema ini dari ketiga reprepresentasi yang disajikan, yaitu grafik, verbal, dan matematis sebagian responden merespon representasi yang diberikan dengan tidak konsisten dalam menyatakan perbandingan kecepatan beberapa benda. Pada representasi grafik, verbal, dan matematis sebagian besar responden merespon dengan konsep yang berbeda-beda. Menurut responden, mereka sulit mendefinisikan data ke dalam berbagai jenis representasi seperti gambar dan grafik. Mereka terbiasa menyelesaikan masalah dalam bentuk format representasi matematis.

\section{Tema Empat, Konsep Gerak Lurus Beraturan (GLB)}

Pemahaman Responden pada tema keempat tentang konsep Gerak Lurus Beraturan (GLB), soal tentang gerak benda yang bergerak dengan kecepatan konstan berdasarkan format verbal dengan menyatakan jenis gerak benda yang bergerak dengan kecepatan konstan dari data rekam jejak pita, format grafik dengan menggambarkan grafik dari benda yang bergerak dengan kecepatan konstan, dan format gambar dengan menggambarkan rekam jejak benda yang bergerak dengan kecepatan konstan dapat dilihat pada kutipan wawancara terhadap R-01 berikut.

(Verbal)

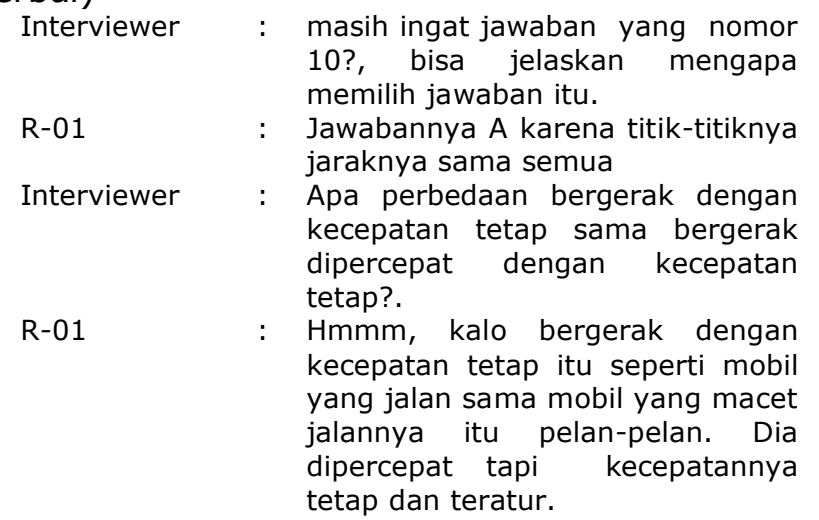

(Grafik)

Interviewer

R-01

Interviewer

$\mathrm{R}-01$

Interviewer

R-01

Interviewer

R-01

Interviewer

\begin{abstract}
Nomor 11 ingat jawabannya? $<$ membaca soal >. A bukan kak? Iya. Terus kenapa memilih A? Hmmm

Menurut kamu posisi adalah?

Tempat kak, letak.

Jadi kenapa memilih A

Karena ini grafiknya yang cocok sama datanya kak, perubahan kecepatannya tetap setiap detiknya.
\end{abstract}

masih ingat jawaban yang nomor 12 ? 
R-01

Interviewer kak,

Kenapa memilih C

R-01 : Hmmm,

R-01 dalam merespon setiap soal tes representasi dalam hal ini representasi dengan format verbar, grafik, dan gambar pada tema empat tentang konsep Gerak Lurus Beraturan (GLB) dengan respon yang sama pada format verbal dan grafik yang kemudian berbeda pada format gambar. Berdasarkan hasil wawancara, menurut R-01 rekam jejak tetesan oli bergerak dengan kecepatan tetap karena jarak antar titik tetesan oli tersebut sama begitu juga pada format grafik, namun pada format gambar mobil mainan yang bergerak dengan kecepatan tetap R-01 memilih gambar rekam jejak mobil mainan dengan jarak antar titik berbeda sehingga R-01 tidak konsisten dengan konsep yang ia gunakan bahwa kecepatan tetap ditunjukkan dengan gambar jarak antar titik tetesan oli tersebut sama.

Pada tema ini dari ketiga reprepresentasi yang disajikan, yaitu verbal, grafik, dan gambar hampir semua siswa merespon representasi yang diberikan dengan konsisten dalam menyatakan jenis gerak benda yang bergerak dengan kecepatan konstan. Pada representasi verbal, grafik, dan gambar sebagian besar responden menyatakan bahwa berdasarkan dari data yang diberikan pada soal menunjukkan bahwa benda bergerak dengan kecepatan tetap.

\section{Tema Lima, Konsep Gerak Lurus Berubah Beraturan (GLBB)}

Pemahaman responden pada tema lima mengenai Gerak Lurus Berubah Beraturan (GLBB) pada format verbal dengan menyatakan jenis gerak benda yang bergerak dengan percepatan konstan dari data gerak benda, format grafik dengan menggambarkan grafik dari sebuah benda yang mengalami gerak lurus dengan percepatan konstan, dan format gambar dengan menggambarkan rekam jejak benda yang bergerak lurus dengan percepatan konstan dapat dilihat pada kutipan wawancara berikut.

$\begin{array}{lll}\begin{array}{l}\text { (Verbal) } \\ \text { Interviewer }\end{array} & : \begin{array}{l}\text { Nomor } \\ \text { jawabannya? }\end{array} \\ \text { R-26 } & : \begin{array}{l}\text { Tidak ingat } \\ \text { Setelah kamu baca apa } \\ \text { Interviewer }\end{array} & \text { jawabannya? } \\ \text { R-26 } & : \begin{array}{l}\text { C mungkin. } \\ \text { Kenapa memilih jawaban C? } \\ \text { Interviewer } \\ \text { R-26 }\end{array} & \begin{array}{l}\text { Kecepatannya ditambah karena } \\ \text { adanya penambahan kecepatan }\end{array}\end{array}$
adanya penambahan kecepatan
(Grafik)

Interviewer : Nomor 14 masih ingat jawabannya?

R-26 : <membaca soal> jawaban saya A karena semakin besar jarak tempuh semakin besar waktunya.

(Gambar)

Interviewer : Nomor 15 masih ingat memilih jawaban apa?

R-26 : <membaca soal> B, pasti salah kak

Pada tema ini dari ketiga reprepresentasi yang disajikan, yaitu verbal, grafik, dan gambar hampir semua siswa merespon representasi yang diberikan dengan konsisten dalam menyatakan gerak benda yang bergerak lurus dengan kecepatan konstan. Pada representasi verbal, grafik, dan gambar sebagian besar responden menyatakan bahwa mobil bergerak dipercepat dengan penambaan kecepatan tetap setiap detiknya hal ini diterapkan pada ketiga format representasi yang disajikan.

Pemahaman R-19 pada tema lima mengenai Gerak Lurus Berubah Beraturan (GLBB) pada format verbal dengan menyatakan jenis gerak benda yang bergerak dengan percepatan konstan dari data gerak benda, format grafik dengan menggambarkan grafik dari sebuah benda yang mengalami gerak lurus dengan percepatan konstan, dan format gambar dengan menggambarkan rekam jejak benda yang bergerak lurus dengan percepatan konstan dapat dilihat pada kutipan wawancara berikut.
(Verbal)

Interviewer : Nomor 13 masih ingat jawabannya? Kenapa memilih jawaban tersebut?

$$
\mathrm{R}-19
$$

Interviewer

$\mathrm{R}-19$

(Grafik) Interviewer

$\mathrm{R}-19$

Interviewer

R1 <membaca soal> C karena jaraknya dipercepat dengan waktunya ditambah

Kalau menurut anda, konsep apa yang dipakai? penambahan bertambah setiap detiknya.

kecepatan
Hmmm, gerak dipercepat dengan

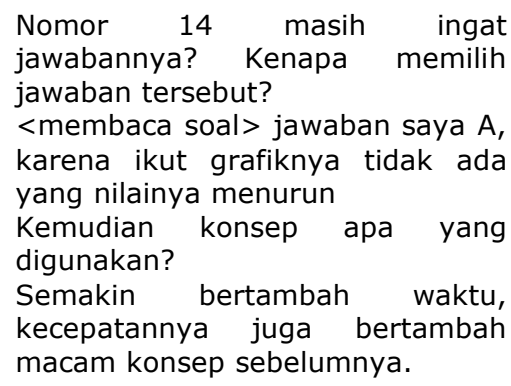

Nomor 14 masih ingat jawabannya? Kenapa memilih jawaban tersebut?

<membaca soal> jawaban saya $A$, karena ikut grafiknya tidak ada yang nilainya menurun

Kemudian konsep apa yang digunakan?

Semakin bertambah waktu, kecepatannya juga bertambah macam konsep sebelumnya. 
(Gambar)

Interviewer

$\mathrm{R}-19$

Nomor $15 \quad$ masih $r$ ingat
jawabannya? Kenapa memilih
jawaban tersebut? <membaca soal> dia makin kebawah makin cepat berarti titiknya makin jarang. Jawabannya D.

R-19 dalam merespon setiap soal tes representasi dalam hal ini representasi matematis, verbal, dan gambar pada tema lima yaitu Gerak Lurus Berubah Beraturan (GLBB) dengan respon yang sama pada setiap representasi pada tema lima yaitu pada representasi verbal, grafik, dan gambar dengan konsep yang sama bahwa semakin bertambah waktu, kecepatannya juga bertambah.

\section{Tema Enam, Gerak Jatuh Bebas}

Pemahaman responden pada tema enam yaitu Gerak jatuh bebas tentang perbandingan waktu tempuh beberapa benda yang mengalami jatuh bebas dengan pernyataan matematis, pernyataan verbal, dan menentukan diagram, tergambar pada kutipan wawancara terhadap R-30 dan R-26 berikut.

(Matematis)

Interviewer : Nomor 16, masih ingat

$\mathrm{R}-30$

Interviewer jawabannya?

$\mathrm{R}-30$

<membaca soal> jawaban saya $\mathrm{C}$ Kenapa memilih C?

Yang duluan sampe yang $2 \mathrm{~kg}$ eh, yang berat. Karena adanya pengaruh massa dan gaya sepertinya kak.

(Verbal)

Interviewer : Nomor 17 masih ingat

$\mathrm{R}-30$

Interviewer

jawabannya?

$<$ membaca soal> jawaban saya C

Kemudian konsep apa yang digunakan?

$\mathrm{R}-30$

Hmmm, Berarti $\mathrm{m} 1$ lebih berat, konsep gerak

(Gambar)

Interviewer : Nomor 18 masih ingat memilih

$\mathrm{R}-30$

Interviewer

jawaban apa?

$<$ membaca soal $>B$

$\mathrm{R}-30$

Kenapa memilih $D$ ? mana yang lebih berat benda $B 2 x$ benda A?

Interviewer : Berarti dari ketiga jawaban kamu yang lebih berat yang duluan sampai? Kemudian konsep apa yang digunakan?

$\mathrm{R}-30$ Iya, konsep gerak.

R-30 dalam merespon setiap soal tes representasi dalam hal ini representasi matematis, verbal, dan gambar pada tema enam dengan respon yang sama yaitu dengan konsep bahwa benda dengan massa berbeda jika dijatuhkan dari ketinggian yang sama, maka yang akan lebih dulu menyentuh tanah yaitu benda yang massanya lebih besar, karena adanya pengaruh massa dan gaya. Hal ini dapat dilihat pada pilihan jawaban R-30 pada tema yang sama yaitu gerak jatuh bebas ia memilih bahwa setiap benda dengan massa yang besar akan lebih cepat menyentuh tanah dibanding benda yang memiliki massa yang kecil walaupun pada representasi gambar nomor delapan belas, dinyatakan bahwa dua buah benda dijatuhkan dalam sebuah ruangan yang divakumkan sedangkan pada representasi matematis dan gambar dinyatakan bahwa dengan mengabaikan hambatan udara dan dengan asumsi gesekan udara tidak mempengaruhi gerak benda.

Hal tersebut menunjukkan bahwa R-30 hanya menebak dengan merepresentasikan konsep secara terstruktur. Seperti halnya penelitian Deliana $^{[8]}$ yang menemukan bahwa karakteristik soal yang sulit memungkinkan siswa menggunakan banyak representasi hal ini disebabkan pada soal yang sulit siswa tidak hanya mampu menebak dan mengandalkan hafalan yang yang mereka telah hafalkan sebelumnya melainkan membutuhkan usaha dengan mempresentasikan konsep secara terstruktur untuk memperoleh jawaban akhir yang diharapkan.

(Matematis)

Interviewer : Nomor 16 masih ingat memilih jawaban yang mana?

$\mathrm{R}-26$

<membaca soal> memang saya tidak tau. Hmm maksud 2Ta apa kak?

Interviewer $\quad:$ Berarti $\mathrm{Tb}=2 \mathrm{Ta}$ yaitu waktu $\mathrm{B}$ dua kali waktu A yang berarti waktu B lebih besar.

$\mathrm{R}-26$

Berarti jawabanku C kak. karena waktu itu saya pikir benda berat itu lebih cepat sampai dari yang ringan berarti yang $4 \mathrm{~kg}$.

(Verbal)

Interviewer : Nomor 17 masih ingat jawabannya?

R1

Interviewer $\mathrm{R}-26$ kak 16 sama 17 Ya

Berarti M1 benda 1, berarti lebih berat M2 berarti M2 lebih cepat sampai.

Interviever Nah pada pilihan jawaban, grafik mana yang sesuai dengan pernyataan kamu?

R-26 Berdasarkan konsep jawabannya A kak.

(Diagram)

Interviewer : Nomor 18 masih ingat

$\mathrm{R}-26$

jawabannya?

$<$ membaca soal> yang benar $\mathrm{C}$ jawabannya kak, waktu itu salah konsep kak.

R-26 dalam merespon setiap soal tes representasi dalam hal ini representasi matematis, verbal, dan gambar pada tema 
enam dengan respon yang berbeda-beda dengan pemahaman konsep yang berubahubah. Hal ini terlihat pada representasi matematis, R-26 ragu pada jawaban semula karena menurutnya waktu itu ia pikir benda berat itu lebih cepat sampai dari yang ringan walaupun gesekan udara diabaikan kemudian juga pada representasi diagram, ia mengubah pilihan jawabannya, menurutnya pada waktu menjawab soal ia salah konsep.

Seperti halnya Novitri dalam penelitiannya menggunakan instrumen soal uraian yang menunjukkan bahwa kemampuan representasi siswa dalam mentransformasikan representasi verbal kerepresentasi grafik sangat rendah sedangkan kemampuan siswa dalam mengubah representasi verbal kerepresentasi grafik memiliki kategori tinggi ${ }^{[9]}$.

Pada tema ini dari ketiga reprepresentasi yang disajikan, yaitu matematis, verbal, dan diagram hampir semua siswa merespon representasi yang diberikan dengan konsisten dalam menyatakan waktu tempuh sampai ke tanah beberapa benda berbeda yang mengalami jatuh bebas. Pada representasi matematis, verbal dan diagram sebagian besar responden menyatakan bahwa dua buah benda dengan massa yang berbeda akan mencapai tanah dengan waktu yang berbeda pula meskipun dengan mengabaikan hambatan udara. Pada tema ini, meskipun menggunakan konsep yang salah tetapi para responden menerapkannya pada semua format representasi pada tema ini secara konsisten.

\section{KESIMPULAN}

Berdasarkan hasil analisis data dan pembahasan maka dapat disimpulkan bahwa konsistensi respon siswa dalam mengerjakan tes representasi terlepas dari benar atau salahnya jawaban dari siswa tersebut, maka sebagian besar siswa berada pada tingkat konsisten dan tidak konsisten sedangkan yang sangat konsisten hanya sebagian kecil.

\section{DAFTAR PUSTAKA}

[1] Nguyen, D and Rebello S,N. (2009). Students Difficulties with Multiple Representation, Dpartment of Physics Kansas State University, Manhattan KS 66502.

[2] Etkina. (2006) "An Averviewof Recent Research on Multirepresentasi" International journal of Science Education.

[3] Kohl, P. B., \& Finkelstein, N. D. (2006). Representational Format, Student Choice, and Problem Solving in Physics. Tersedia http://www.colorado.edu/physics/EducationIssues/pap ers/PK_PERC.pdf. [14 februari 2014].

[4] Nieminen. P. (2010). Force Concept Inventory-Based Multiple-Choice Test For Investigating Students'
Representational Consistency. Department of Teacher Education, University of Jyväskylä, Jyväskylä FIN40014, Finland.

[5] Waldrip, B dan Prain, V. (2006)." An Exploratory Study of Teachers' and Students' Use of Multi-Modal Representations of Concepts in Primary Science". International Journal of Science Education. 28, (15), (1843-1896).

[6] Meltzer, E. D. (2005) Relation Between Students Problem-Solving Performance and Representational Format. American Journal of Physics.73. no.5.

[7] Rosengrant, D. Etkina and A. Heuvelent (2006). " $A n$ Overview of Recearch on Multiple Representations". Rutgers, The State University of New]ersey.[online].Tersedia:http://www.paer.rutgers.E du./scientificabilities/downloads/FormAssesTasks/Multi Rep.pdf.(1 juni 2015)

[8] Deliana, E. (2012). Kemampuan Multi Representasi Siswa alam Menjawab Soal Tes Uraian Materi Cermin Lengkung di SMP. Skripsi sarjana pada FPS UPI Bandung: tidak diterbitkan

[9] Novitri, A (2013). Kemampuan Mahasiswa dalam Melakukan Transformasi Representasi Eksternal. Tesis [10] 